\title{
NOTE
}

\section{High pressure synthesis of a new aluminium silicate: $\mathrm{Al}_{5} \mathrm{Si}_{5} \mathrm{O}_{17}(\mathrm{OH})$}

\author{
R. A. Eggleton ${ }^{1}$, J. N. Boland ${ }^{2}$ and A. E. Ringwood ${ }^{2}$ \\ Geology Department ${ }^{1}$ and Research School of Earth Sciences, ${ }^{2}$ \\ Australian National University, P.O. Box 4, Canberra A.C.T. 2600 Australia
}

(Received February 17, 1978)

\begin{abstract}
A new aluminium silicate has been produced under hydrous conditions from $\mathrm{Al}_{2} \mathrm{O}_{3}-\mathrm{SiO}_{2}$ oxide mixes with $\mathrm{Si} / \mathrm{Al}$ ratios close to unity, at pressures greater than 100 kilobars and at about $1,000^{\circ} \mathrm{C}$. X-ray powder photographs indicated one dominant new phase. From analyses of the electron diffraction Laue zones of minute fragments $(\sim 1 \mu \mathrm{m})$, a monoclinic structure that fitted the X-ray powder results was identified. This monoclinic structure is described in terms of nine close-packed layers of oxygen with the unit cell containing 72 oxygen atoms. Assuming Si/Al equals 1, the composition of this phase is $\mathrm{Al}_{20} \mathrm{Si}_{20} \mathrm{O}_{72} \mathrm{H}_{4}$ The calculated density of $4.03 \mathrm{~g} / \mathrm{cc}$ is in good agreement with the value of $4.02 \mathrm{~g} / \mathrm{cc}$ estimated from the refractive index measurements.
\end{abstract}

\section{INTRODUCTION}

The synthesis, stability fields and properties of anhydrous and hydrous aluminium silicates have received a great deal of attention in the literature. However, most of the work reported so far has been carried out at pressures smaller than $50 \mathrm{~kb}$. We describe here the results of some reconnaissance experiments on aluminium silicate systems in the pressure range 50-150 $\mathrm{kb}$, and at elevated temperatures.

\section{EXPERIMENTAL}

Starting materials used in the present experiments consisted of homogeneous glasses with compositions $\mathrm{Al}_{2} \mathrm{O}_{3} \cdot 3 \mathrm{SiO}_{2}, \mathrm{Al}_{2} \mathrm{O}_{3} \cdot 2 \mathrm{SiO}_{2}$, natural pyrophyllite $\mathrm{Al}_{2} \mathrm{O}_{3} \cdot 4 \mathrm{SiO}_{2} \cdot \mathrm{H}_{2} \mathrm{O}$, natural kaolinite $\mathrm{Al}_{2} \mathrm{O}_{3} \cdot 2 \mathrm{SiO}_{2} \cdot 2 \mathrm{H}_{2} \mathrm{O}$, heated gels of compositions $\mathrm{Al}_{2} \mathrm{O}_{3} \cdot 2 \mathrm{SiO}_{2} \cdot \mathrm{xH}_{2} \mathrm{O}$ containing respectively $15,10,3$ and zero percent of water, and heated gels of composition $2 \mathrm{Al}_{2} \mathrm{O}_{3} \cdot 3 \mathrm{SiO}_{2}$ containing 5 and 15 percent of water.

Samples of these materials were placed in a Bridgman-anvil apparatus containing an internal heater (RINGWOOD and MAJOR, 1968). Experimental runs were carried out over a range of pressures from 50 to $150 \mathrm{~kb}$ whilst the sample was heated simultaneously to about $1,000^{\circ} \mathrm{C}$. Average run-time was 5 minutes although some runs of 20 minutes duration were carried out. After completion of runs, samples were removed from the apparatus and examined by optical microscopical and X-ray methods. In addition, certain key runs were studied by electron microscopy and electron diffraction.

\section{RESULTS}

$X$-ray and optical data The glasses either failed to crystallize (even in 20 minute runs) or else yielded poorly crystallized phases, mostly possessing diffuse X-ray diffraction lines. Evidently, the temperatures attained in the apparatus used were too low to permit devitrification to well-crystallized equilibrium phases. A few runs below $90 \mathrm{~kb}$ yielded some coesite + kyanite, whereas at higher pressure, the products could not be characterized. Likewise, a run on the dehydrated $\mathrm{Al}_{2} \mathrm{O}_{3} \cdot 2 \mathrm{SiO}_{2}$ gel yielded indeterminate products. A series of runs on the hydrated gels at pressures smaller than $90 \mathrm{~kb}$ yielded coesite plus a well-crystallized unidentified phase which has yet to be characterized. The remainder of this paper will be concerned with the results of runs on hydrated gels, pyrophyllite, and kaolinite at pressures greater than $100 \mathrm{~kb}$ and at about $1,000^{\circ} \mathrm{C}$.

Under these conditions, pyrophyllite was observed to transform to a mixture of stishovite plus a new phase possessing a complex but sharply resolved X-ray diffraction pattern. Likewise, kaolinite transformed to the new phase plus a trace $(<5 \%)$ of stishovite. The hydrated 
gels, $\mathrm{Al}_{2} \mathrm{O}_{3} \cdot 2 \mathrm{SiO}_{2} \cdot \mathrm{xH}_{2} \mathrm{O}$ also transformed into quite well-crystallized samples of the new phase plus variable amounts (5-25\%) of stishovite, additional lines from a third phase were present. Evidently, complete equilibrium was not attained in the runs on gels.

X-ray diffraction data for the new phase (corrected for systematic errors using stishovite and added silicon as internal standards) are given in Table 1. The mean refractive index of the new phase was found to be $1.757 \pm .005$, determined on a sample consisting of anhedral birefringent crystals with a grain size of a few microns.

The drastic decrease in the amount of excess stishovite in runs using kaolinite $(\mathrm{Si} / \mathrm{Al}=1)$ which transformed to $>95 \%$ of the new phase and $<5 \%$ of stishovite, compared with pyrophylite runs $(\mathrm{Si} / \mathrm{Al}=2)$, strongly suggests that the new phase has an $\mathrm{Si} / \mathrm{Al}$ ratio close to unity. The very small amount of excess stishovite observed in the kaolinite runs would permit the $\mathrm{Si} / \mathrm{Al}$ ratio to be slightly smaller than unity. Because of apparently incomplete attainment of equilibrium, runs on the gels with $\mathrm{Si} / \mathrm{Al}=$ 1 were less definitive. However, it is significant that those runs which contained the minimum amount of a third phase also contained minimum amounts of excess stishovite. They imply, therefore, that the composition of the new phase has an $\mathrm{Si} / \mathrm{Al}$ ratio very close to unity with the possibility of a slight deficiency of $\mathrm{SiO}_{2}$.

Two runs were carried out on a hydrous gel composition $2 \mathrm{Al}_{2} \mathrm{O}_{3} \cdot 3 \mathrm{SiO}_{2}$ at $120 \mathrm{~kb}$. Both runs transformed completely to a mixture of corundum plus stishovite; no trace of the new phase was seen. These results are somewhat surprising in that a mixture of the new phase plus corundum or stishovite might have been anticipated according to whether the new phase had an $\mathrm{Si} / \mathrm{Al}$ ratio smaller or greater than 0.75 . However, the inability to synthesize the new phase at an $\mathrm{Si} / \mathrm{Al}$ ratio of 0.75 combined with its ready and almost complete synthesis at $\mathrm{Si} /$ $\mathrm{Al}=1$ strongly suggests that its composition is likely to be closer to the latter than the former.

It should be noted that the new phase has only been synthesized from starting materials containing substantial quantities of water. In no case were even small amounts of this phase produced during runs on dehydrated gels or glass starting materials although a wide range of other poorly crystallized phases were produced under these conditions. Moreover, LIU (pers. com.)
Table 1. X-ray data showing d-spacings ( $\AA$ ) and (hkl) based on the monoclinic phase in Table 2

\begin{tabular}{|c|c|c|}
\hline I & d & hkl \\
\hline 5 & 5.34 & 001 \\
\hline 3 & 3.98 & $\overline{2} 01$ \\
\hline 10 & 3.67 & $\overline{2} 21$ \\
\hline 1 & 3.54 & \\
\hline 1 & 3.44 & 131 \\
\hline 2 & 3.36 & 150 \\
\hline 1 & 2.74 & 151 \\
\hline 1 & 2.695 & \\
\hline 4 & 2.649 & $\overline{1} 12$ \\
\hline 10 & 2.616 & $\underline{002}$ \\
\hline 7 & 2.450 & $\underline{1} 32$ \\
\hline 3 & 2.334 & $\overline{3} 51$ \\
\hline 6 & 2.301 & $\underline{4} 20$ \\
\hline 3 & 2.129 & $\overline{441}$ \\
\hline 9 & 2.054 & 280 \\
\hline 10 & 2.031 & 222 \\
\hline 6 & 2.014 & $\underline{370}$ \\
\hline 6 & 1.881 & $\overline{1} 91$ \\
\hline 1 & 1.832 & \\
\hline 6 & 1.807 & 312 \\
\hline 3 & 1.775 & $\overline{1} 13$ \\
\hline 2 & 1.678 & $\overline{5} 32, \overline{4} 62$ \\
\hline 4 & 1.666 & 461 \\
\hline 1 & 1.641 & $\overline{3} 33$ \\
\hline 1 & 1.630 & $\overline{6} 01$ \\
\hline 10 & 1.587 & 600 \\
\hline 9 & 1.574 & $\underline{1} .11 .1$ \\
\hline 10 & 1.570 & 423 \\
\hline 2 & 1.544 & $\overline{3} 53$ \\
\hline 7 & 1.514 & 551 \\
\hline 2 & 1.502 & $\bar{\sigma} 22,481$ \\
\hline 6 & 1.425 & $\overline{3} 73$ \\
\hline 3 & 1.413 & $\overline{463}$ \\
\hline 4 & 1.387 & 590 \\
\hline 1 & 1.372 & 2.10 .2 \\
\hline 8 & 1.346 & 4.10 .1 \\
\hline 2 & 1.322 & $\overline{5} 92$ \\
\hline 6 & 1.314 & $\overline{7} 32,0.12 .2$ \\
\hline 5 & 1.298 & 482 \\
\hline
\end{tabular}

has demonstrated using diamond anvils with laser heating that anhydrous glasses with $\mathrm{Al} / \mathrm{Si}$ ratios of $1 / 4,1 / 2,1$ and 2 crystallized to kyanite \pm corundum and kyanite \pm stishovite at pressures between 120 and $150 \mathrm{~kb}\left(\sim 1,200^{\circ} \mathrm{C}\right)$. Above $150 \mathrm{~kb}$, all these compositions crystallized to mixtures of corundum plus stishovite. Our own results, in conjunction with those of LIU, strongly imply that the new phase contains essential $(\mathrm{OH})^{-1}$ in its structure.

The mean refractive of the new phase (1.757) may be compared with the mean refractive indices of corundum (1.763), coesite (1.595), stishovite (1.814) and kyanite (1.723). Evidently, the new phase is extremely closepacked and dense. Crude estimates of its density may be obtained from molar refractivity argu- 
ments (S TAFFord and Silverman, 1947; DACHILLE and ROY, 1959). If we assume that its formula is $\mathrm{Al}_{2} \mathrm{O}_{3} \cdot 2 \mathrm{SiO}_{2}$ and that silicon atoms are octahedrally coordinated (taking the molar refractivity of $\mathrm{Si}^{\text {ii }} \mathrm{O}_{2}$ as in stishovite to be $6.07 \mathrm{cc}$ ), then the density would be $4.02 \mathrm{~g} / \mathrm{cm}^{3}$. On the other hand, if we assume that the silicon atoms are tetrahedrally coordinated (taking the molar refractivity of $\mathrm{Si}^{\mathrm{iv}} \mathrm{O}_{2}$ to be $7.01 \mathrm{cc}$, as in coesite and kyanite) then the density would be $3.71 \mathrm{~g} / \mathrm{cm}^{3}$. These estimates ignore the effects of possible slight deviations from $\mathrm{Si} / \mathrm{Al}=1$ stoichiometry and of the possible presence of essential $(\mathrm{OH})^{-1}$ in the structure. Nevertheless, they are indicative.

\section{Electron microscopy Samples selected for} electron microscopy were crushed between glass slides, carbon coated and floated onto copper grids (MCLAREN and PhaKey, 1965). Several grids were coated with aluminium to provide an in situ standard for the electron diffraction patterns. Based on particle morphology, microstructure and the diffraction patterns, it was apparent that several phases were present in the samples. Besides the crystalline material, small particles (100 to $500 \AA)$ of amorphous material were found.

One microstructural type consisted of a 1 to $2 \mu \mathrm{m}$ aggregate of fine grained material with an average grain size of $300 \AA$. The diffraction patterns from these aggregates showed spotty rings; the d-spacings calculated from the patterns showed only partial agreement with the spacings listed in Table 1. Occasionally, isolated single crystals, about $500 \AA$ in size, could be tilted into various Laue zones from which estimates of the unit cell parameters were made. Two other microstructural types were found in the larger particles ( 0.1 to $1 \mu \mathrm{m}$ size range). One consisted of a phase having a high dislocation density $\left(10^{9}\right.$ dislocation $\left./ \mathrm{cm}^{2}\right)$; this phase was unstable in the electron beam. The irradiation damage was initiated as small loop-type structures about $200 \AA$ in diameter. These loops grew in size and the material within the loops was found to be amorphous. After prolonged exposure to the beam, the amorphous regions consumed the surrounding crystalline material rendering the whole fragment amorphous. The second type of particle exhibited a prominent cleavage and had planar defects lying in the cleavage plane (AMELINCKx, 1970); the d-spacing of the planes containing the defects was $\sim 9.5 \AA$ which corresponded with (100) in the
Table 2. Unit cell dimensions ( $\AA$ ) based on electron diffraction

\begin{tabular}{cccc}
\hline \hline Cell & Triclinic & Monoclinic-C & Orthorhombic \\
\hline a & 4.60 & 9.81 & 8.52 \\
b & 10.5 & 18.1 & 5.12 \\
c & 19.4 & 5.36 & 10.5 \\
$\alpha$ & 90 & & \\
$\beta$ & 99.6 & $105^{\circ}$ & \\
$\gamma$ & 92 & & \\
\hline
\end{tabular}

monoclinic phase described below.

Structure From an analysis of over 100 Laue zones, no single lattice could be found to fit all the zones. In Table 2 are listed 3 lattices, each satisfying certain sets of diffraction data.

The X-ray data best fit the monoclinic Clattice. The cell dimensions, obtained by leastsquares refinement using 24 reflections indexed according to this cell (standard deviations in parentheses) are $a=9.802(3) \AA, b=18.213(7) \AA$, $c=5.363(2) \AA, \beta=103.73(5)^{\circ}$. This cell contains 9 closest-packed layers of oxygens of radius $\mathrm{r}_{\mathrm{ox}}=1.32$, having $c=4 \mathrm{r}_{\mathrm{ox}}, b=9\left(\sqrt{\frac{2}{3}}\right) \mathrm{r}_{\mathrm{ox}}$, $\mathrm{d}_{100}=c \sqrt{3}, \tan \beta=\mathrm{c} / 2 \mathrm{~d}_{100}$. Such a cell contains 72 oxygens, and assuming $\mathrm{Al} / \mathrm{Si}=1$, must have composition $\mathrm{Al}_{20} \mathrm{Si}_{20} \mathrm{O}_{72} \mathrm{H}_{4}$. The water which appears to be necessary to synthesize the new phase, thus is present as structural $(\mathrm{OH})$. The calculated density for this cell is 4.03 , in excellent agreement with the value of 4.02 estimated from refractive index. Only 3 weak lines in the $\mathrm{X}$-ray pattern cannot be indexed on this cell, and these lines are attributed to one of the other phases found by electron diffraction. These phases as well as the amorphous material, may represent metastable transformation products of the high pressure phase. Some of the transformations were most likely induced during the crushing stage of sample preparation. Unfortunately, samples prepared by dispersing the powder on the carbon film contained only the polycrystalline aggregates from which no single crystal X-ray data could be resolved.

\section{IMPLICATIONS}

The fact that pyrophyllite is observed to transform to this new phase plus stishovite at pressures exceeding $100 \mathrm{~kb}$ and at temperatures of about $800^{\circ} \mathrm{C}$ has some significant implications for current high pressure techniques (AKIMOTо et al., 1977). Pyrophyllite is often used as a pressure medium or as components of the pressure cells in high $\mathrm{P}, \mathrm{T}$ apparatus. The 
pressure calibrations in most such apparati are usually based upon phase transitions in standard metals or compounds measured at ambient temperature. However, at pressures of about $100 \mathrm{~kb}$ and at elevated temperatures, pyrophyllite itself will transform to much denser phases as described above, resulting in considerable contraction of volume within the pressure cell and consequent loss of pressure. Pyrophyllite is likely to be an inefficient pressure medium under these conditions and its use in pressure cells is likely to lead to considerable overestimates of the pressures actually attained during experiments at extremely high $\mathrm{P}$ and $\mathrm{T}$.

\section{REFERENCES}

AKImoto, S., YAGI, T., and InOUE, K. (1977) High temperature pressure phase boundaries in silicate systems using in situ X-ray diffraction, in High-pressure research: Applications in Geophysics, M.
Manghnani and S. AKImoto eds., Academic Press, New York, 585-602.

AMELINCKX, S. (1970) The study of planar interfaces by means of electron microscopy, in Modern diffraction and imaging techniques in materials sciences, S. AMELINCKX, R. GeVers, G. Remaut, J. VAN L ANDUYT, eds., North-Holland Publishing Co., London, 257-294.

DACHILlE, F. and RoY, R. (1959) The use of infrared absorption and molar refractivities to check coordination. Z. Krist. 111, 462-470.

MClaren, A. C. and PhaKeY, P. P. (1965) A transmission electron microscope study of amethyst and citrine. Aust. J. Phys. 18, 135-141.

RINGWOOD, A. E., and MAJOR, A. (1968) Apparatus for phase transformation studies at high pressures and temperatures. Phys. Earth Planet. Interiors 1, 164-168.

SAFFORD, A. E., and Silverman, A. (1947) Aluminasilica relationships in glass. J. Am. Ceram. Soc. 30, 203-211. 